\title{
Government Ownership and Dividend Payment Policy
}

\author{
Pavita Bayu Permata Putri ${ }^{\bowtie}$, Arief Yulianto \\ Management Department, Faculty of Economics, Universitas Negeri Semarang, Semarang, Indonesia
}

Article Information

Article History:

Received January 2020

Approved February 2020

Published June 2020

Keywords:

Government Ownership,

Dividend Payment Policy.

\begin{abstract}
The purpose of this study to examine and analyze differences in the average policy of dividend payments with government ownership in companies listed on the Indonesia Stock Exchange in period 2008-2017. Previous research still shows differences in research results or inconsistent results between one study and another. The results showed that the average dividend payment policy carried out by the government was higher than companies that did not have government ownership. This is considered as government ownership, so the amount of dividends distributed will increase. Based on the results of this study it can be concluded that government ownership provides an average higher dividend payment policy than non-government ownership. Suggestions for company management, in making dividend payment policies, the company should always consider the interests of the company's owners. Investors should pay attention to factors outside the economy in investing. For further researchers, it can be used as an additional reference and research can be done one by one sector.
\end{abstract}

\section{INTRODUCTION}

One topic that is often discussed and interesting issues in agency theory is dividend policy. Dividend policy is one of the most important policies for every company. Dividend policy is a decision on whether profits derived by a company will be distributed to shareholders as dividends or will be retained in the form of retained earnings for investment financing in the future (Sartono, 2001). For shareholders, dividends are a form of payment made by companies both in cash and shares in return for the proportion of the number of shares owned by investors. Horne and Wachowicz (1997) states that determining earnings as retained earnings and dividend payments are the main aspects of dividend policy. Dividends are very important for investors, therefore dividends are part of the reasons for investors to become shareholders of a company (Cao, 2016).
Dividend distribution is largely influenced by investor behavior which generally prefers high dividend distribution, resulting in lower retained earnings (Sari \& Wijayanto, 2015). According to Agustina and Ardiansari (2015) dividend payments are important because dividend payments provide certainty about the financial position of a company and dividend policy taken by the company will lead to investor perceptions of the company. This is because the company paying the dividend is considered a good signal for investors when the company is in good condition, so investors are interested in investing in the company. According to Abiprayu and Wiratama (2016) the condition that must be met in order for a company to distribute dividends is that the company must have a positive net income.

According to Yulianto et al. (2014) dividend policy is the substitution of capital structure in textile companies and complementary mechanisms

(C) 2020 Universitas Negeri Semarang

\footnotetext{
Correspondence Address:

L2 Building, 1st Floor, Faculty of Economics, Universitas Negeri Semarang

Jalan Taman Siswa, Sekaran, Gunungpati, Semarang, 50229

E-mail: pavitapermata@gmail.com
} 
without ownership structure in reducing agency problems. Dividend policy will have a positive impact on company performance (Rochana \& Wijayanto, 2018). Dividend policy has an appeal for shareholders, so it needs to be considered. Juma'h and Pacheco (2008) suggested that there are several objectives in dividend distribution. First, to maximize shareholder prosperity, because the high and stable dividends paid will affect the stock price. Second, to show the company's liquidity, by paying dividends, it is expected that the company's performance in the eyes of investors will look good. Third, to show that the company is able to deal with the economic turmoil that occurs, as well as illustrate the company's ability to provide results to investors. Fourth, to attract investors because some investors view the risk of dividends is lower than the risk of capital gains. The size of the dividend distributed depends on the dividend policy of each company.

Dividend policy which is proxied by using the dividend payout ratio has a positive effect on the value of the company, because the greater the dividend distributed will affect investors, so that it will cause positive sentiment or a good perception about the company that will be the place of investment (Cahyaningdyah \& Ressany, 2012). Companies that benefit and increase the possibility of investing will pay dividends, so companies that pay dividends can choose funding sources that come from profits or from debt (Yulianto et al., 2015). According to Prasetyo (2013) dividend payments can provide control over agency conflicts, so company performance will be better.

In making decisions such as dividend policy can not be separated from conflicts between shareholders and managers, conflicts that are often referred to as agency problems (agency conflict) that will lead to agency costs (Erfiana \& Ardiansari, 2016). Agency theory explains that agency relationships arise when one or more people (principals) employ another person (agent) to provide a service and then delegate decision-making authority to the agent (Jensen \& Meckling, 1976). The difference in interests between the principal and the agent will lead to agency conflict. Agency conflict occurs because managers make decisions that are not the same as those of shareholders. Agency problems like this are called type 1 agency problems.

While type 2 agency problems are agency problems that occur between majority shareholders and minority shareholders (Cahyani \& Sanjaya, 2014). This type 2 agency problem occurs in concentrated ownership structures. Agency problems arise when controlling shareholders try to obtain private benefits that do not benefit non-controlling shareholders. The controlling shareholder can transfer wealth, or get special benefits through transactions between the controlling shareholder and the controlled company (Gilson \& Gordon, 2003).

Agency conflict can cause management or controlling shareholders to take actions aimed at their own interests (Setiawan \& Sari, 2014). One form of action that benefits oneself is through acts of expropriation. Expropriation in this case is very likely to occur in companies in Indonesia because companies in Indonesia are concentrated and the rights of non-controlling shareholders are very low. This condition is an incentive for controlling shareholders to conduct expropriation of non-controlling shareholders. Expropriation is an act of expropriation of minority rights by the majority. According to Claessens et al. (2000) expropriation is the process of using controls to maximize one's own welfare with the distribution of wealth from other parties.

According to agency theory, the greater the concentration of ownership, then shareholders can use dividends to limit the opportunities for managers to conduct expropriation, so that the dividends distributed are also greater (Rahmawati, 2019). In companies like this, the founders became bound by control and made it possible to make decisions in taking over the rights of investors outside (Claessens et al., 2002). In addition, Claessens et al. (2000) said that the fact that in Indonesia voting rights (control rights) that exceed cash flow rights could lead to implications that controlling shareholders have the ability and incentives to expropriate minority shareholders.

Agency problems and acts of expropriation by the majority shareholder can be resolved by dividend payments made by the company (E. Setiawan \& Sari, 2014). Dividend payments increase when government ownership increases in the Chinese market (Chen et al., 2009). The government is categorized as a controlling shareholder because the objectives of the government controlling the company are relatively different from the objectives of the other controlling shareholders. Shleifer and Vishny (1994), said that generally the government controls companies for the purpose of improving people's welfare and political objectives.

Government ownership is the number or proportion of shares owned by the government which are generally found in state-owned companies or SOEs (Setiawan et al., 2016). According to Shleifer and Vishny (1986), government ownership is a party that can monitor company management. Companies with government ownership have the main task, which is to assist the 
government in improving the welfare of the community. To be able to improve the welfare of the community, a company with ownership will influence the dividend policy that will be generated by the company (Wuisan et al., 2018).

The following is data on the average amount of dividend payments distributed by government ownership and the average dividend payments distributed by non-government ownership in 2008-2017:

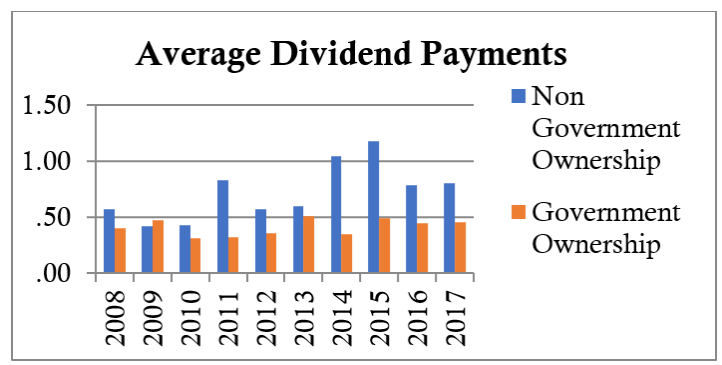

Source : Cash Dividends for 2008-2017, Data processed (2019)

Figure 1. Average Dividend Payments distributed by government ownership and Non-Government Ownership in Companies 2008-2017

Figure 1 shows the average dividend payment policy as measured by the Dividend Payout Ratio (DPR) in companies that have government ownership from year to year tends to fluctuate. This shows that the presence of government ownership raises the question of whether actually government ownership will provide benefits or will result in losses. The author considers that it is important to find out how significant is the relationship between government ownership and dividend payment policies.

However, if seen in the graph, the average movement of dividend payment policy of government-owned companies from year to year, which is 2008-2017, shows lower results than the average policy of dividend payment of non-governmentowned companies. This phenomenon is contradictory or not in accordance with research (Le \& Le, 2017) which proves that government-owned companies pay higher dividends than non-government-owned companies. The company owned by the government has a high agency problem. This is because government ownership companies often carry out expropriations. So to reduce this agency problem, dividend payments will be made.

Based on several studies conducted on government ownership of dividend policy, there are still differences. According to research results Setiawan et al. (2016) the government as controlling shareholder, encourages managers to pay higher dividends to finance national development. Pham et al. (2018) states that government ownership has a positive effect on dividend policy. Meanwhile, according to the results of research Ben-nasr (2015), Al-najjar and Kilincarslan (2016), and Wuisan et al. (2018) states that government ownership negatively influences dividend policy. In addition to the above research results, the results of the research of Bradford et al. (2013) and Le and Le (2017) stated that there are differences in the average policy of dividend payments with government ownership. However, Warrad et al. (2012) states that there is no relationship between dividend policy and government ownership.

\section{Hypothesis Development}

There are differences in dividend policy in SOEs and private companies (Carney \& Child, 2013). The main task of government companies is to assist the government in improving social welfare and supporting the government's goals in development, besides that it is sometimes demanded to pay high dividends to the government, while private companies have the main goal of earning profits and the welfare of shareholders. Companies with government ownership distribute higher dividends than non-government owned companies because companies with government ownership help the government to prosper the community while nongovernment owned companies prefer not to pay dividends due to the company's operational activities.

Companies with government ownership as majority shareholders can get support from the government to obtain external sources such as favorable loan terms (Le \& Chizema, 2011). Bradford et al. (2013) states that companies with government ownership are easier to make loans from financial institutions or banks than non-government owned companies, so government-owned companies tend to pay higher dividends. Conversely, non-government owned companies prefer not to pay dividends because it is beneficial for the company's operations.

According to Wang et al. (2011) companies with large state ownership can pay higher cash dividends to signify their positive performance. Chen, et al. (2009) states that companies controlled by the government distribute high dividends, so that government ownership has a positive effect on dividend policy. This is in line with the results of the study of Bradford, et al. (2013) and Thanatawee (2014) that there is a positive influence between government ownership of dividend policy. As a transfer of state shares can only be realized with government approval, the tactic of paying high dividends can facilitate the state in transferring a portion of shares that cannot be traded to other shareholders (Le \& Le, 2017). Supported by 
Le and Le (2017) research results that the positive and significant coefficient of government ownership revealed that companies privatized with the state as the largest shareholder would pay a higher dividend than the base company (the company with the largest shareholder as a local investor).

Thus, it can be concluded that companies with government ownership distribute higher dividends than non-government owned companies. Thus there is a difference in the average dividend payment policy between government-owned companies and non-government-owned companies.

$\mathrm{H} 1$ : There is a difference between the average dividend payment policy and government ownership owned by the company.

\section{METHOD}

This type of research is a type of explanatory research using quantitative research methods that can be interpreted research methods used for research on certain participants or samples. The data used in this study is a collection of data using secondary data. Data collection consists of time series data elements and data cross sections (Gujarati \& Porter, 2015). The data used is the panel is not balanced or the panel is not balanced because the number of observations of time units differ for each entity or individual. The sampling technique is done by using purposive sampling or based on certain criteria established by researchers.

Table 1. Purposive Sampling

\begin{tabular}{lll}
\hline No & Information & Total \\
\hline 1 & $\begin{array}{l}\text { Companies listed on the Indone- } \\
\text { sia Stock Exchange for the period }\end{array}$ & 4610 \\
& 2008-2017
\end{tabular}

2 Companies that did not pay divi- -2765 dends during period 2008-2017

3 Companies with negative dividend -92 Number of final samples

Source: List of issuers on the Indonesia Stock Exchange 2008-2017

The method used is a dummy variable regression analysis using the variance analysis model (ANOVA). The variables used in this study consisted of one dependent variable and one independent variable. The dependent variable in this study is the Dividend Payout Ratio and the independent variable used is Government Ownership. The dividend policy variable in this study is proxied by the Dividend Payout Ratio. Dividend policy measured by using a dividend payout ratio shows how much the proportion of profit distributed as dividends (Jayanti \& Puspitasari, 2017). Dividend payout ratio is considered as the most appropriate variable that represents the company's dividend policy (Rozeff, 1982).

According to Setiawan et al. (2016) Government Ownership is the number or proportion of shares owned by the government which are generally found in state-owned companies and SOEs. Government ownership is measured by a dummy variable, if the company is worth 1 government ownership and if not, government ownership is 0 .

The data collection technique used is documentation, which is a method of collecting secondary data from various sources, both personal and ICMD that have been published through the company's official website and www.idx.co.id which are sampled in research (Sanusi, 2017).

\section{RESULT AND DISCUSSION}

\section{Descriptive Statistical Analysis}

The following results are descriptive statistics dividend value. According to Ghozali (2011), descriptive statistics aim to provide a description or description of a data that is seen from the average, standard deviation, maximum value and minimum value.

Table 2. Descriptive Test Results

\begin{tabular}{llll}
\hline GOV & Mean & Std. Dev. & Obs. \\
\hline 0 & 0.782582 & 4.516 .104 & 1595 \\
1 & 0.494442 & 0.771549 & 158 \\
All & 0.756611 & 4.314 .633 & 1753 \\
\hline
\end{tabular}

Source: Output Eviews 9, data processed (2019)

Based on table 2 it can be seen the number of samples used in this study were 1,753 units of observation. The number of observation units is a total sample of all companies that distribute dividends listed on the Indonesia Stock Exchange during the 10-year observation period, from 2008 to 2017.

\section{Normality test}

There are two ways to detect data normality, namely by graphical analysis and statistical tests. In the normality test the statistical test is done by looking at the probability value. If the probability is $<0.05$, then the distribution of residual variables is not normal, while the probability $>0.05$, then the distribution of residual variables is normally distributed. The following are the results of the normality test in this study: 
Following are the descriptive test results after the normality test.

Table 3. Descriptive Test Results after normal

\begin{tabular}{llll}
\hline GOV & Mean & Std. Dev. & Obs. \\
\hline 0 & 0.396329 & 0.404058 & 1513 \\
1 & 0.497577 & 0.773008 & 157 \\
All & 0.405848 & 0.452361 & 1670
\end{tabular}

Source: Output Eviews 9, processed data (2019)

Based on table 3 it can be seen that the dividend policy in companies that have share ownership by the government shows an average of 0.4976 . The average value is higher than the dividend policy in companies that do not have government share ownership, which is 0.3963 .

\section{Homogeneity Variance Test}

Homogeneity variance test is carried out with the aim to find out the similarity of variance in each test group. As a testing criterion, if the significance value is more than 0.05 , it can be said that the variants of two or more groups of data are the same. Homogeneity testing is carried out with the Barlett test, as shown in table 4 below:

Table 4. Results of Variance Homogeneity Tests

\begin{tabular}{llll}
\hline Method & df & Value & Probability \\
F-test & $(156.1512)$ & 1.260 .333 & 0.0415 \\
Siegel- & & 2.627 .055 & 0.0086 \\
Tukey & & 3.548 .491 & 0.0596 \\
Bartlett & 1 & 5.143 .596 & 0.0235 \\
Levene & $(1.1668)$ & \\
Brown- & $(1.1668)$ & 5.638 .828 & 0.0177 \\
Forsythe & \multicolumn{3}{l}{ Source: Output Eviews 9, processed data (2019) }
\end{tabular}

Based on table 4 can be seen from the results of the Barlett test shows the probability va- lue of $0.0596>0.05$. The results above indicate the probability value is greater with a significance level of 0.05 , it can be concluded that the variance in the two ownership groups has a homogeneous or equal variance.

\section{Anova analysis}

Table 5. Anova Analysis Results

\begin{tabular}{lll}
\hline Method & Value & Probability \\
\hline t-test & -2.79431 & 0.0053 \\
Satterthwaite-Welch & -3.06924 & 0.0024 \\
t-test* & & \\
Anova F-test & 7.808193 & 0.0053 \\
Welch F-test* & 9.420257 & 0.0024 \\
\hline Source: Output Eviews 9, processed data (2019)
\end{tabular}

Anova test results showed the value of F test was 7.808 with a significance of 0.0053 $<0.05$. Thus, the sample of two ownership groups has different dividend policies. In other words, government ownership has a significant influence on dividend policy.

\section{Goodness of Fit Test}

According to (Gujarati \& Porter, 2015), the magnitude of R2 is known as the coefficient of determination (sample) which is the most commonly used measure to measure the Goodness of Fit of a regression line. This value looks at how much the proportion or presentation of the effect of independent variables on the dependent variable.

Based on table 6 can be seen the results of the coefficient of determination test, the value of R2 is 0.004269 . It can be said that as much as $0.4 \%$ the dependent variable is proxied by the DPR (dividend payout ratio) which can be explained by the independent variable (Government Ownership). While the remaining $99.6 \%$ is explained by other factors beyond the independent variables not included in this research model.

Table 6. Coefficient of Determination Results

\begin{tabular}{llll}
\hline R-squared & 0.004269 & Mean dependent var & 0.405848 \\
Adjusted R-squared & 0.003672 & S.D. dependent var & 0.452361 \\
S.E. of regression & 0.451529 & Akaike info criterion & 1.248844 \\
Sum squared resid & 340.0696 & Schwarz criterion & 1.255336 \\
Log likelihood & -1040.785 & Hannan-Quinn criter. & 1.251249 \\
F-statistic & 7.151890 & Durbin-Watson stat & 2.016154 \\
Prob(F-statistic) & 0.007562 & & \\
\hline Source: Output Eviews 9, processed data (2019) & &
\end{tabular}




\section{Research Hypothesis Test}

Individual statistical tests ( $\mathrm{t}$ test statistics) show how far the influence of one independent variable on the dependent variable by assuming if the other independent variables are constant (Imam Ghozali \& Ratmono, 2013). The results of the statistical t test with the dependent variable DPR can be seen in table 7 .

Table 7. T-Statistical Results

\begin{tabular}{lllll}
\hline $\begin{array}{l}\text { Vari- } \\
\text { able }\end{array}$ & $\begin{array}{l}\text { Coeffi- } \\
\text { cient }\end{array}$ & $\begin{array}{l}\text { Std. Er- } \\
\text { ror }\end{array}$ & $\begin{array}{l}\text { t-Sta- } \\
\text { tistic }\end{array}$ & Prob. \\
\hline C & 0.396329 & 0.011608 & 3.414 & 0.0000 \\
GOV & 0.101248 & 0.037859 & 2.674 & 0.0076
\end{tabular}

Source: Output Eviews 9, processed data (2019)

Based on table 7, it can be seen that the results of the statistical t test on government ownership variables obtained a coefficient value of 0.101248 with a $t$ value of statistics of 2.674302 and a probability value of 0.0076 . Judging from the value of the probability of government ownership of $0.0076<0.05$, which means that this indicates that there are significant differences in the average dividend policy then $\mathrm{H} 1$ is accepted.

Farooque et al. (2007) Government Ownership is the number of shares owned by the government of all managed capital shares. The existence of government ownership, can provide benefits for companies, including providing the influence of company management in dividend distribution decisions.

Agency theory is a theory that explains the differences in interests that occur between agents (managers) and principals (shareholders). The conflict between agent and principal here is type I conflict, whereas type II conflict is between principal and principal. According to Al-Malkawi et al. (2013) government ownership as the company's largest shareholder can affect dividend policy. The company is controlled by the state, in this case the government acts on behalf of the main owner who is not involved in the control so that agency problems arise between managers and government representatives because they do not work for the manager's interests and on the other hand between state ownership and other managers. Dividend payments in this case can reduce the cash flow available to managers and can therefore help alleviate agency problems. Therefore the results of this study are in accordance with agency cost theory that government owned companies pay more dividends.
The results of this study indicate that the independent variable, namely government ownership, has an average difference in the dividend policy of all companies distributing dividends listed on the Indonesia Stock Exchange for the period 2008 to 2017. The existence of a significant average difference is also statistically evidenced. The average difference in Dividend Payout Ratio as a measure of the company's dividend policy means it has results that are consistent with agency theory. Agency theory states that government ownership tends to pay higher dividends than non-government ownership.

Indonesia as a country with a civil law legal system has weak investor protection so investors in Indonesia tend to like dividends (Mayapada \& Kahar, 2017). Shareholders tend to receive dividends regardless of whether the company is growing or not due to weak investor protection. Due to the high level of uncertainty about whether or not investors are deceived investors prefer dividends rather than investing in (Ferris et al., 2009).

Companies controlled by the government have the duty to increase the people's prosperity, therefore companies controlled by the government generally pay higher dividends in order to support the government's goals in carrying out development. Chen et al. (2009) states that companies controlled by the government distribute high dividends, so that government ownership has a positive effect on dividend policy. Likewise, Bradford et al. (2013) states that compared to non-government companies, companies owned by the government pay higher dividends.

The hypothesis proposed in this study is that there are differences in the average policy of dividend payments with government ownership owned by companies. It can be seen in the above research hypothesis test that the government ownership variable has a positive coefficient sign that is equal to 0.101248 and the significance value at prob $0.0076(0.0076<0.05)$ which means that there are significant differences in the average dividend policy so the hypothesis be accepted. In other words, companies that have a number of government ownership can be said to be dividing more evenly. The results of this study are supported by statements (Pham et al., 2018) that companies with government ownership tend to pay higher dividends than non-government owned companies.

\section{CONCLUSION AND RECOMMENDATION}

The difference in the average value of dividend payment policies at companies listed on the Indonesia Stock Exchange in 2008-2017 is eviden- 
ced by looking at the results of the average value directly from the coefficient and statistically by looking at the probability value. The results of research on government ownership of dividend policy in accordance with the hypothesis that has been developed that there is a difference in the average dividend payment policy with government ownership. This shows that there is a higher dividend payment policy on government ownership compared to non-government ownership, which is in accordance with agency theory. Companies controlled by the government are tasked with increasing people's prosperity, therefore companies controlled by the government generally pay dividends. higher order in order to support the government's goals in carrying out development. The use of government ownership variables has not been widely used in research related to dividend payment policies. It is hoped that this research can become a reference and further research can be carried out by sampling from one sector at a time, so that it is more focused.

\section{REFERENCES}

Abiprayu, K. B., \& Wiratama, B. (2016). Does Ceo's Hubris Affecting Dividends Payout? Apakah Ceo Hubris Mempengaruhi Dividen Payout? Jurnal Dinamika Manajemen, 7(1), 66-75.

Al-Malkawi, H.-A. N., Twairesh, A. E., \& Harery, K. (2013). Determinants of the Likelihood to Pay Dividends : Evidence from Saudi Arabia. Journal of American Science, 9(12), 518-528.

Al-Najjar, B., \& Kilincarslan, E. (2016). The Effect of Ownership Structure on Dividend Policy : Evidence from Turkey. The International Journal of Business in Society, 16(1), 135-161.

Anita, A., Yulianto, A., Manajemen, J., Ekonomi, F., Semarang, U. N., \& Artikel, I. (2016). Pengaruh Kepemilikan Manajerial dan Kebijakan Dividen terhadap Nilai Perusahaan. Management Analysis Journal, 5(1), 17-23.

Ben-nasr, H. (2015). Government Ownership and Dividend Policy : Evidence from Newly Privatized Firms, 1-59.

Bradford, W., Chen, C., \& Zhu, S. (2013). Cash Dividend Policy, Corporate Pyramids, and Ownership Structure : Evidence from China. International Review of Economics and Finance, 27, 445-464.

Brigham, \& Houston. (2011). Dasar-Dasar Manajemen Keuangan. Jakarta : Salemba Empat.

Cahyani, K. A., \& Sanjaya, I. P. S. (2014). Analisis Perbedaan Dividen pada Perusahaan Keluarga dan Non Keluarga Berdasarkan Kepemilikan Ultimat. MODUS, 26(2), 133-144.

Cahyaningdyah, D., \& Ressany, Y. D. (2012). Pengaruh Kebijakan Manajemen Keuangan terhadap Nilai Perusahaan. Jurnal Dinamika Manajemen, 3(1), 20-28.

Cao, C. (2016). Does Religion Matter to Dividend Policy? Evidence from Buddhism and Taoism in China. Nankai Business Review International.

Carney, R. W., \& Child, T. B. (2013). Changes to the Ownership and Control of East Asian Corporations between 1996 and 2008: The Primacy of Politics. Journal of Financial Economics, 107(2), 494-513.

Chen, D., Jian, M., \& Xu, M. (2009). Dividends for Tunneling in a Regulated Economy : The Case of China. Pacific-Basin Finance Journal, 17(2), 209-223.

Claessens, S., Djankov, S., Fan, J. P. H., \& Lang, L. H. P. (2002). Disentangling the Incentive and Entrenchment Effects of Large Shareholdings. The Journal of Finance, 57(6), 2741-2771.

Claessens, S., Djankov, S., \& Lang, L. H. P. (2000). The Separation of Ownership and Control in East Asian Corporations. Journal of Fiancial Economics, 58, 81-112.

Erfiana, D., \& Ardiansari, A. (2016). Pengaruh Masalah Keagenan, Kebijakan Dividen, dan Variabel Moderasi Growth Opportunity terhadap Nilai Perusahaan. Management Analysis Journal, 5(3), 244-256.

Eugene F, B., \& Joel F, H. (2006). Dasar-dasar Manajemen Keuangan (Edisi 10).

Faccio, M., \& Lang, L. H. P. (2002). The Ultimate Ownership of Western European Corporations. Journal of Financial Economics, 65, 365-395.

Fakhriyyah, D. D., Purnomosidhi, B., \& Subekti, I. (2017). Pengaruh Tata Kelola terhadap Praktik Ekspropriasi dengan Kebijakan Dividen sebagai Variabel Pemoderasi. Jurnal Ilmiah Manajemen, 7(3), 465-483.

Farooque, O. Al, Zijl, T. Van, Dunstan, K., \& Karim, A. K. M. W. (2007). Corporate Governance in Bangladesh : Link between Ownership and Financial Performance. Journal Compilation, 15(6), 1453-1468

Ferris, S. P., Jayaraman, N., \& Sabherwal, S. (2009). Catering Effects in Corporate Dividend Policy : The International Evidence. Journal of Banking and Finance, 33(9), 1730-1738.

Gilson, R. J., \& Gordon, J. N. (2003). Controlling Shareholders. University of Pennsylvania Law Review, 152(785), 785-843.

Gujarati \& Porter. (2015). Dasar-Dasar Ekonometrika (5th ed.). Jakarta : Salemba Empat.

He, T. T., Li, W. X. B., \& Tang, G. Y. N. (2012). Dividends Behavior in State-Versus Family-Controlled Firms: Evidence from Hong Kong. Springer, 97-112.

Horne, V., \& Wachowicz. (1997). Prinsip-Prinsip Manajemen Keuangan. Salemba Empat : Jakarta.

Imam Ghozali \& Ratmono. (2013). Analisis Multivariat dan Ekonometrika. FEB Universitas Diponegoro Semarang.

Ismiati, P. I., \& Yuniati, T. (2017). Pengaruh Kepemilikan Manajerial, Kepemilikan Institusional dan Kebijakan Hutang terhadap Kebijakan Dividen. Jurnal Ilmu dan Riset Manajemen, 6(3), 1-19.

Jayanti, I. S. D., \& Puspitasari, A. F. (2017). Struktur Kepemilikan dan Kebijakan Dividen pada Pe- 
rusahaan Manufaktur di Indonesia. The Indonesian Journal of Applied Business, 1(1), 1-13.

Jensen, M. C., \& Meckling, W. H. (1976). Theory of the Firm : Managerial Behavior, Agency Costs and Ownership Structure. Journal of Fiancial Economics, 3(4), 305-360.

Juma'h, A. H., \& Pacheco, C. J. O. (2008). The Financial Factors Influencing Cash Dividend Policy : A Sample of U.S. Manufacturing Companies. Inter Metro Business Journal, 4(2), 23-43.

Khoiruddin, M., \& Faizati, E. R. (2014). Reaksi Pasar terhadap Dividend Announcement Perusahaan yang Sahamnya Masuk Daftar Efek Syariah. Jurnal Dinamika Manajemen, 5(2), 209-219.

Kikeri, S., Nellis, J., \& Shirley, M. (1992). PRIVATIZATION The Lessons of Experience. A World Bank Publication.

Le, T., \& Chizema, A. (2011). State ownership and firm performance : Evidence from the Chinese listed firms. Organizations and Markets in Emerging Economies, 2(2), 72-90.

Le, T. V., \& Le, T. H. (2017). Ownership and Identities of the Largest Shareholders and Dividend Policy : Evidence from Vietnam. Organizations and Markets in Emerging Economies, 8, 86-104.

Mayapada, A. G., \& Kahar, A. (2017). Pengaruh Sistem Hukum terhadap Manajemen Laba dengan Mekanisme Corporate Governance sebagai Variabel Pemoderasi (Studi pada Perusahaan Industri Barang Konsumsi yang Terdaftar di Bursa Efek Indonesia dan Bursa Malaysia). Jurnal Katalogis, 5(8), 182-190.

Mulyono, B. (2009). Pengaruh Debt to Equity Ratio, Insider Ownership, Size dan Investment Opportunity Set terhadap Kebijakan Dividen. Thesis, Universitas Diponegoro. Retrieved from Thesis, Universitas Diponegoro

Nursandari, M. (2015). Analisis Faktor yang Mempengaruhi Kebijakan Dividen dengan Size (Ukuran Perusahaan) sebagai Variabel Moderasi pada Perusahaan Manufaktur Yang Terdaftar di Bursa Efek Indonesia. Skripsi.

Pham, H. T. T., Jung, S.-C., \& Nguyen, H. T. D. (2018). The Impact of Government Ownership on Dividend Policy: Case in Vietnam and Taiwan, 1-28.

Porta, R. La, Lopez-de-silanes, F., \& Shleifer, A. (1998). Corporate Ownership Around the World. NBER Working Paper Series.

Porta, R. La, Lopez-de-Silanes, F., Shleifer, A., \& Vishny, R. (1999). The Quality of Government. The Journal of Law, Economics, \& Organization, 15(1), 222-279.

Prasetyo, T. (2013). Dividen, Hutang, dan Kepemilikan Institusional di Pasar Modal Indonesia : Pengujian Teori Keagenan. Jurnal Dinamika Manajemen, 4(1), 10-22.

Rahmawati, D. N. (2019). Pengaruh Struktur Kepemilikan dan Growth Opportunity pada Perusahaan Keluarga yang terdaftar di Bursa Efek Indonesia (BEI) Periode 2015-2017. Skripsi Universitas Islam Indonesia.

Ross, B. S. A. (1973). The Economic Theory of Agen- cy : The Principal's Problem. American Economic Association, 63(2), 134-139.

Rozeff, M. S. (1982). Growth, Beta and Agency Costs as Determinants of Dividend Payout Ratios. The Journal of Financial Research, 5(3), 249-259.

Sanusi, A. (2017). Metodologi Penelitian Bisnis. Jakarta : Salemba Empat.

Sari, E. L., \& Wijayanto, A. (2015). Pengaruh Keputusan Investasi, Pendanaan, dan Dividen terhadap Nilai Perusahaan dengan Risiko sebagai Variabel Mediasi. Management Analysis Journal, 4(4), 281-291.

Sartono, A. (2001). Manajemen Keuangan Teori dan Aplikasi Edisi 4. Yogyakarta : BPFE.

Setiawan, D., Bandi, B., Phua, L. K., \& Trinugroho, I. (2016). Ownership Structure and Dividend Policy in Indonesia. Journal of Asia Business Studies, 10(3), 230-252.

Setiawan, E., \& Sari, D. (2014). Analisis Pengaruh Ekspropriasi dan Koneksi Politik terhadap Kebijakan Dividen Tunai Perusahaan. Universitas Indonesia, 1-20.

Shleifer, A., \& Vishny, R. W. (1986). Large Shareholders and Corporate Control. Journal of Political Economy, 94(3), 461-488.

Shleifer, A., \& Vishny, R. W. (1994). Politicians and Firms. The Quarterly Journal of Economics, 9951025.

Shleifer, A., \& Vishny, R. W. (1997). A Survey of Corporate Governance. The Journal of Finance, 52(2), 737-783.

Simorangkir, I. G., \& Sadalia, I. (2010). Analisis Pengaruh Rasio Keuangan dan Potensi Pertumbuhan serta Ukuran Perusahaan terhadap Kebijakan Dividen (Studi Kasus di Bursa Efek Indonesia). Jurnal Ekonom, 13(1), 1-8.

Sugiyono. (2017). Metode Penelitian Kuantitatif, Kualitatif, dan $R \& D$. Bandung : Alfabeta.

Thanatawee, Y. (2014). Ownership Structure and Dividend Policy : Evidence from China. International Journal of Economics and Finance, 6(8), 197-204.

Wang, X., Manry, D., \& Wandler, S. (2011). The Impact of Government Ownership on Dividend Policy in China. International Journal of Cardiology, 27(2), 366-372.

Warrad, L., Abed, S., Khriasat, O., \& Al-Sheikh, I. (2012). The Effect of Ownership Structure on Dividend Payout Policy : Evidence from Jordanian Context. International Journal of Economics and Finance, 4(2), 187-195.

Wuisan, F., Randa, F., \& Lukman. (2018). Pengaruh Struktur Kepemilikan terhadap Kebijakan Dividen Perusahaan. Simak, 16(2), 119-141.

Yulianto, A. (2013). Keputusan Struktur Modal dan Kebijakan Dividen sebagai Mekanisme Mengurangi Masalah Keagenan. Jurnal Dinamika Manajemen, 4(2), 161-179.

Yulianto, A., Aji, D., \& Widiyanto, S. (2015). Testing Pecking Order Theory and Trade off Theory Models in Public Companies in Indonesia. Handbook on Business Strategy and Social Sciences, 3, 13-18. 